\title{
NUANSA HEGEMONIS ASOSIATIF DALAM PENAMAAN KULINER MASYARAKAT URBAN SURABAYA
}

\author{
Dian Purnama Sari \\ STKIP Bina Insan Mandiri. dianpurnamasari@stkipbim.ac.id
}

\begin{abstract}
ABSTRAK
Nama-nama kuliner masa kini di Surabaya sebagai kota urban sangat bervariasi dan memunculkan makna asosiatif.. Tujuan dalam penelitian ini adalah mendeskripsikan makna asosiatif yang terbentuk dari nama kuliner di Surabaya serta mendeskripsikan nuansa hegemonis yang melekat di dalamnya. Jenis penelitian ini adalah kualitatif deskriptif, sumber data adalah masyarakat urban Surabaya dan datanya berupa namanama kuliner yang diciptakan. Peneliti menggunakan korpus data penganalisisan. Penamaan kuliner masyarakat urban sarat dengan makna asosiatif yang konotatif berbeda dengan nama-nama kuliner pada masa lalu, merepresentasikan kondisi psikis masyarakat tersebut karena penamaan adalah media dari bahasa yang merupakan cerminan otak dan jiwa pemakainya, Nuansa hegemoni kapital seputar perbedaan kelas, eksploitasi, dan penindasan tercermin dalam nama-nama makanan yang dikonsumsi oleh masyarakat urban di Surabaya khususnya. Masyarakat yang terhegemoni belum sampai pada titik menjadi penyintas, masih meratapi nasib dan baper asosiatif lewat nama-nama kuliner yang diciptakannya. Upaya membangun mental masyarakat agar tidak terus merasa sebagai pihak terhegomoni bisa diawali dengan penciptaan frasafrasa atau istilah-istilah kuliner yang optimis.
\end{abstract}

Kata Kunci : Hegemoni Asosiatif, Nama Kuliner, Masyarakat Urban

\begin{abstract}
The purpose of this research is to describe the associative meaning that is formed from the culinary name in Surabaya and to describe the hegemonic nuances inherent in it. This type of research is descriptive qualitative, the data source is the Surabaya urban community and the data is in the form of culinary names that were created. Researchers use a corpus data analyzing. The naming of urban culinary is full of associative meanings that have different connotations from culinary names in the past, representing the psychic condition of the community because naming is a medium of language which is a reflection of the brain and soul of the wearer, the nuances of capital hegemony around class differences, exploitation and oppression. reflected in the names of foods consumed by the urban community in Surabaya in particular. A hegemonic society has not yet reached the point of becoming a survivor, still lamenting the fate and associative baper through the culinary names it created. Efforts to build the community's mentality so as not to continue to feel like a hegemonic victim can be started with the creation of optimistic culinary phrases or terms.
\end{abstract}

Keywords: Associative Hegemony, Culinary Name, Urban Society 


\section{PENDAHULUAN}

Manusia adalah unsur utama pembentuk kebudayaan masyarakat. Salah satu hasil budaya tersebut adalah kuliner atau makanan. Setiap jenis makanan dinamai berdasarkan hasil kesepakatan bersama, dikonsumsi publik, dan dikenal dengan nama tersebut dari masa ke masa. Tanpa disadari nama-nama kuliner tersebut menjadi representasi kondisi masyarakat pada masa tertentu.

Pada masa lalu masyarakat lebih kerap menyebut nama makanan apa adanya, misalnya Ayam Pedas Manis, Ayam Kecap, Bakso Sapi, Bakso Solo (karena cabang dari Solo), Sate Kambing, Es Dawet Jepara (karena khas Jepara), Soto Lamongan, dan lain-lain. Hal tersebut sangat berbeda dengan masyarakat hari ini, khususnya di wilayah Surabaya yang notabene adalah masyarakat urban atau pendatang. Masyarakat urban lebih berani menamai makanan dengan namanama unik bahkan terkesan "mekso" misalnya pada makanan Rawon Pecel, Bebek Ngenes, Es Genderuwo, Mie Setan, dan masih banyak nama lain yang terkesan eksentrik bahkan menakutkan.

Banyak faktor yang menyebabkan munculnya makanan dengan nama-nama aneh tersebut, diantaranya desakan persaingan bisnis kuliner yang semakin ramai dan menuntut produk yang berbeda agar didatangi konsumen sehingga ide-ide aneh dan mekso tersebut muncul, media TV yang banyak menayangkan tutorial masak dengan menu dan nama yang bervariasi, media sosial yang berperan aktif memajang makanan yang instagramable untuk promosi, juga urbanisasi yang secara luwes membentuk mental masyarakat kota menjadi lebih ekspresif menamai produk makanannya tersebut. Khusus dikaitkan dengan fenomena masyarakat urban yang menjual produk makanan di Surabaya, tanpa disadari nama-nama makanan dan minuman yang terbentuk merepresentasikan psikis masyarakat urban tersebut. Desakan persaingan dagang dan kekangan kapitalisme menggambarkan nama-nama makanan yang sarat penderitaan, kesedihan, keterjeratan akan kelas sosial, serta penuh ketakutan.

Aktivitas berbahasa lewat penamaan tersebut didorong oleh kekuatan roh dalam diri yang memiliki kepentingan untuk diutarakan. Hal 
tersebut selaras dengan ungkapan Eco (2009:242) bahwa tanda hanyalah menjadi tanda ketika ia digunakan untuk menamai sesuatu. Penamaan tersebut muncul sebagai ide yang lahir dari rasa serta karsa penciptanya, sarat dengan segala kondisi psikis yang dialaminya. Tidak dapat dipungkiri rata-rata masyarakat urban yang datang ke Surabaya adalah untuk bekerja (menghasilkan uang). Urban lekat dengan dunia buruh, wirausaha yang merintis dari nol, harus bersaing dengan bisnis-bisnis gaya baru semacam francise, e-commerce, dan lain-lain. Kondisi semacam itulah yang melahirkan nama-nama makanan 'penuh derita' yang dijual ke publik dan publik juga menikmatinya. Dalam hal ini baik penjual maupun pembeli berposisi sebagai korban hegemoni kapitalis yang merasa tidak masalah membeli makanan dengan nama-nama aneh lantaran hasrat konsumerisme yang tinggi.

Makna asosiatif dalam payung Semantik untuk membahas penamaan kuliner ini mengacu pada teori Leech. Leech (dalam Chaer, 2002:72) menyebutkan makna asosiatif termasuk makna konotatif, stilistik, afektif, refleksi, dan kolokatif. Makna asosiatif sama dengan perlambang-perlambang yang digunakan oleh suatu masyarakat bahasa untuk menyatakan suatu konsep lain. Peneliti mengaitkan makna asosiatif tersebut dengan teori hegemoni Gramsci karena penciptanya adalah masyarakat urban Surabaya yang merupakan pelaku persaingan kelas dalam menjalankan usaha kulinernya. Ratarata masyarakat urban perkotaan adalah buruh atau pelaku bisnis menengah, terdapat kelas dominan di atasnya yang lebih berkuasa. Gramsci (dalam Qomaruddin, 2017) menjelaskan bahwa hegemoni merupakan sebuah proses penguasaan kelas dominan kepada kelas bawah, dan kelas bawah juga aktif mendukung ide-ide kelas dominan. Penguasaan dilakukan tidak dengan kekerasan, melainkan melalui bentuk-bentuk persetujuan masyarakat yang dikuasai. Bentuk-bentuk persetujuan masyarakat atas nilai-nilai masyarakat dominan dilakukan dengan penguasaan basis-basis pikiran, kemampuan kritis, dan kemampuan-kemampuan afektif masyarakat melalui konsensus yang menggiring kesadaran masyarakat tentang masalah-masalah sosial ke dalam pola 
kerangka yang ditentukan lewat birokrasi (masyarakat dominan), terlihat adanya usaha untuk membuat natural suatu bentuk dan makna kelompok yang berkuasa.

Sumber data dalam penelitian ini diperoleh di seluruh wilayah Surabaya yang datanya berupa nama-nama kuliner tersebut. Tujuan dalam penelitian ini adalah mendeskripsikan makna asosiatif yang terbentuk dari nama kuliner di Surabaya serta mendeskripsikan nuansa hegemonis yang melekat di dalamnya. Jenis penelitian ini adalah kualitatif deskriptif. Penekanan penelitian terletak pada upaya mendeskripsikan secara rinci makna asosiatif serta unsur hegemonis dalam nama kuliner. Peneliti menggunakan korpus data dalam upaya penganalisisannya.

\section{PEMBAHASAN}

\section{a. Makna Asosiatif dalam Penamaan Kuliner Masyarakat Urban Surabaya}

Berdasarkan penelusuran, peneliti mendata 50 nama kuliner yang bermakna asosiatif. Data pertama yaitu berupa frasa Tempe Penyet. Makna tempe secara konseptual adalah makanan yang terbuat dari kedelai. Penyet berasal dari bahasa Jawa yang berarti sesuatu yang gepeng, hancur, bengkok, tidak seperti sedia kala bisa karena tekanan atau tindasan. Makna konseptual yang muncul dari frasa tempe penyet tempe dalam keadaan gepeng/hancur sebelum dimakan biasanya dilengkapi dengan sambal. Asosiasi dari makna reflektif yang muncul adalah aktivitas menindas/menghancurkan dulu sebelum dimakan. Biasanya tempe penyet dilengkapi dengan sambal saat menghancurkannya di cobek. Makna asosiatif yang terbentuk dalam frasa Tempe penyet tersebut mirip prosesnya dengan frasa Ayam Geprek (data 3), Tahu Gejrot (data 27), Kue Cubit (30). Refleksi proses penindasan dan penghancuran sangat tampak dari diksi yang digunakan dalam nama makanan tersebut. Pateda (2010:179) menyatakan bahwa makna asosiasi dapat dihubungkan dengan waktu atau peristiwa. Peneliti menggaris bawahi peristiwa sama dengan proses. Jadi terdapat proses dalam frasa-frasa tersebut, proses yang terkesan menyakiti. 
Temuan peneliti selanjutnya pada data 2 terdapat istilah Bebek Ngenes. Secara konseptual kata bebek bermakna itik. Ngenes bermakna rasa kecewa, sangat sedih. Maka dapat dimaknai secara afektif bahwa bebek ngenes dapat bermakna makanan yang bahan utamanya adalah olahan bebek diberi sambal yang sangat pedas. Oleh sebab itulah disebut bebek ngenes karena kondisi pedas membuat orang yang memakannya menderita. Muncul nuansa kesadisan ketika mendengar nama makanan ini. Bila memang pedas itu nikmat mengapa tidak dinamai bebek ceria atau bebek pedas saja, karena ngenes hanya bisa dirasakan oleh manusia umumnya. Makna asosiatif yang berupa afektif juga muncul pada makanan dengan nama Ayam Nelongso (data 4).

Selanjutnya, terdapat juga frasa Ayam Kelas Kakap (data 5). Secara konseptual ayam berarti unggas, kelas kakap berarti bukan kelas teri. Makna konotatif yang terbentuk dari frasa tersebut adalah masakan ayamnya tingkat tinggi atau kelas atas. Hanya saja kesan yang terbentuk karena penggunaan istilah kelas tersebut adalah semacam kelas sosial, sarat nuansa kapitalisme (bernuansa hegemonis kapitalis) melalui makna asosiasi yang sengaja diciptakan di dalam frasa tersebut. Selain itu terdapat juga Sate Kere (data 6), keduanya berkonotasi kelas atau level. Secara Konseptual kata kere berasal dari bahasa Jawa yang artinya orang yang sangat miskin, gembel, pengemis, peminta-minta. Konotasi dari kata kere untuk penamaan makanan yaitu sate bermakna potongan dagingnya kecil-kecil sama halnya dengan Sate Laler (data 7). Data lain yang berkaitan dengan kelas ini adalah makanan Sego Ndodok (data 14). Ndodok/ndhodhok berasal dari bahasa Jawa yang berarti jongkok. (tidak duduk di kursi), secara asosiatif makna yang dapat ditangkap ketika makan dalam posisi jongkok tentu tidak lazim dan tidak baik, namun memang penjual tidak menyediakan tempat duduk jadi pembeli jongkok saat makan, Begitu pula dengan Rawon Kalkulator (data 19). Meskipun Rawon Kalkulator sebenarnya berkaitan dengan penjualnya yang cepat sekali saat menghitung pembeli harus bayar berapa namun kesan angka-angka, spekulasi, dan capital sangat bertalian dengan istilah kalkulator. Berikutnya adalah Tahu Kratos (data 28), secara konseptual tahu adalah makanan yang terbuat dari kedelai sedangkan kratos 
berasal dari bahasa Yunani yang berarti Pemerintahan atau kekuasaan. Jadi makna asosiatif yang dapat ditangkap di dalamnya adalah ada nuansa kuasa dalam makanan tersebut, entah pedagangnya yang baru menggoreng tahunya ketika pembeli meminta (pembeli yang berkuasa) atau setelah makan tahu kratos tersebut pembeli jadi ketagihan beli lagi dan datang lagi ke penjualnya (penjual yang berkuasa).

Beberapa makanan berasosiasi seksual karena frasanya dibangun dengan menyebutkan bagian tubuh, maupun istilah yang terkesan nakal. Frasa makanan tersebut semacam Mi Seksi (data 10), Sego bokong (data 16), Nasi Goreng Pelakor (data 17), Ayam Kampus (data 35), Mie Pecun (data 36), dan Es Peler Bedebu (data 37). Makna Asosiatif yang terbentuk dari konotasi-konotasi seksual tersebut sebenarnya secara nyata tidak demikian adanya. Disebut mi seksi karena mi yang digunakan penjual adalah mie keriting tapi tampak lenggak-lenggoknya sehingga secara asosiatif terkesan seksi. Demikian juga dengan sego bokong, disebut begitu karena pedagangnya berjualan keliling menggunakan sepeda kayuh yang bagian boncengannya diberi dua kota kanan kiri untuk tempat nasi pecel yang dijualnya sehingga posisi dagangan di boncengannya, begitu juga untuk makna frasa yang lain.

Temuan peneliti berikutnya adalah nama kuliner yang bermakna asosiatif ketakutan. Konotasi ketakutan tersebut dibentuk dari istilah hantu-hantuan, aktivitas kekerasan, sifat yang mengerikan, dan objek-objek yang berpotensi bahaya. Makna misalnya Mie Setan (data 8), Mie Petir (data 11), Rawon Setan (data 18), Ceker Setan (data 29), Es Genderuwo (data 31), Es Covid (data 33), Pentol Darurat (data 34), Mi Bledek (data 38), Bakso Lava (data 21), Bakso Granat (data 22), Bakso Ranjau (data 23), Sego Jotos (data 13), Sego Sadukan (data 12), Mie Judes (data 9). Terkait Es Covid, penjual cenderung menamai dagangannya sesuai dengan objek yang sedang populer, meskipun secara makna konseptual Covid adalah virus yang membawa penyakit tetap saya penjual menggunakannya karena sedang populer. 
b. Nuansa Hegemonis Asosiatif dalam Penamaan Kuliner Masyarakat Urban Surabaya

Masyarakat Urban Surabaya terbagi menjadi tiga budaya yaitu budaya Arek, budaya Mataraman, dan budaya Pandalungan. Budaya Arek meliputi pendatang dari Mojokerto, Gresik, Surabaya, dan Malang. Budaya Mataraman meliputi pendatang dari Nganjuk, Jombang, Kediri, dan Tuban. Sedangkan budaya Pandalungan meliputi pendatang dari Jember, Pasuruan, termasuk Madura. Surabaya sebagai wilayah Provinsi Jawa Timur memang menampung banyak masyarakat pendatang yang mengadu nasib. Dalam proses bercampurnya masyarakat dari berbagai wilayah tersebut timbul pula istilahistilah serapan dari berbagai daerah digunakan secara familiar di Surabaya. Hal tersebut juga memengaruhi istilah-istilah yang berkembang dipakai dalam komunikasi sehari-hari di Surabaya. Percampuran kebahasaan tersebut turut mendominasi penamaan-penamaan kuliner di Surabaya. Nuansa hegemonis asosiatif berkembang, ketumpang tindihan makna kadang tidak dapat dihindari karena semua istilah tumbuh subur digunakan oleh masyarakat urban tersebut. Untuk menggalinya lebih dalam perlu digaris bawahi dulu maksud dari hegemoni dalam ulasan ini.

Teori hegemoni dikemukakan oleh Gramsci, seorang tokoh sosialis Italia. Gramsci mengungkapkan hegemoni adalah suatu praktik dominasi kekuatan pemerintah (state) terhadap publik (people / civic) dengan cara "halus". Hegemoni adalah suatu dominasi kekuasaan suatu kelas sosial atas kelas sosial lainnya melalui kepemimpinan intelektual dan moral yang dibantu dengan dominasi atau penindasan. Hegemoni memiliki beberapa cara yaitu melalui kekerasan, mengarahkan pemikiran, konsensus baik melalui lembaga sosial maupun dengan menanamkan ideologi. Praktik hegemoni ini terefleksikan sejak poskolonial hingga saat ini. Praktik hegemoni dalam keseharian dilakukan dengan berbagai cara dipakai untuk terus melakukan hegemoni, misalnya melalui institusi yang ada dalam masyarakat, sehingga menentukan secara langsung struktur kognitif dalam masyarakat. Oleh karena itu, hegemoni pada hakikatnya upaya untuk menggiring seseorang agar memandang problematika sosial dalam kerangka yang ditentukan 
Terkait dengan penamaan kuliner masyarakat urban tersebut, hegemoni kapital tanpa disadari memberi pengaruh sangat besar terhadap nama-nama kuliner yang dihasilkan. Nama-nama kuliner bernuansa penderitaan, kesakitan, dan penindasan merupakan representasi dari hidup keseharian masyarakat urban. Nama-nama kuliner tersebut jauh dari keceriaan dan kesenangan tampak sekali dari ulasan sebelumnya. Penggunaan istilah penyet, geprek, gejrot, sadukan, jotos, darurat granat, cubit nelongso, semua bernuansa kesakitan, korban, dan penderitaan. Begitu juga dengan istilah-istilah fasis militer seperti ranjau, granat, dan objek-objek berbahaya lainnya yaitu lava, gledek, petir sangat menggambarkan kondisi psikis masyarakat yang terhegemoni oleh kesulitankesulitan harian.

Bahasa adalah apapun yang ada di dalam pikiran pemakainya. Namanama kuliner tersebut merupakan cerminan dari keresahan masyarakat seharihari akan kebutuhan makan dan bertahan hidup. Meskipun demikian, bisa jadi pikiran masyarakat terkait tidak menyadari bahwa penamaan tersebut adalah bentuk lelah dan protes karena menganggap itu makanan sehari-hari. Penulis Das Capital, Marx mengungkapkan bahwa awalnya adalah tragedi, kemudian jadi lelucon. Senada dengan fenomena masyarakat yang alam bawah sadarnya secara spontan mengamini nama-nama kuliner tersebut dalam kesehariannya untuk dipakai sebagai cerminan kondisi psikis penuh kesakitan yang dialami akibat kekuasaan kapitalisme.

Kesadaran akan kelas sosial juga tergambar dalam nama kuliner yang tercipta seperti Ayam Kelas Kakap, Tahu Kratos, Rawon Kalkulator seperti yang telah diulas sebelumnya, Nuansa hegemoni, perihal yang superior dan inferior sangat tampak dari nama-nama kuliner tersebut. Tidak hanya nuansa kelas sosial, kecarut marutan kondisi masyarakat urban yang batas kelasnya sangat tampak dan sering melarikan diri, melampiaskannya lewat saling merundung juga tampan nyata dalam nama kuliner Pempek Bujang Tuo, Bakso Bujangan. Juga eksploitasi gender tertentu lewat makna asosiasi yang sengaja dibuat untuk menarik pelanggan tampak pada penggunaan nama Mi Seksi dan Ayam Kampus. 


\section{SIMPULAN}

Berdasarkan analisis, ulasan, dan bahasan yang telah diuraikan sebelumnya dapat disimpulkan bahwa.

a. Penamaan kuliner masyarakat urban sarat dengan makna asosiatif yang konotatif dan berbeda dengan nama-nama kuliner pada masa lalu.

b. Nama-nama kuliner masyarakat urban merepresentasikan kondisi psikis masyarakat tersebut karena penamaan adalah media dari bahasa yang merupakan cerminan otak dan jiwa pemakainya,

c. Nuansa hegemoni capital seputar perbedaan kelas, eksploitasi, dan penindasan tercermin dalam nama-nama makanan yang dikonsumsi oleh masyarakat urban di Surabaya khususnya.

d. Nuansa hegemoni yang bersifat fasis militeris juga tampak dalam penciptaan nama kuliner, misalnya dengan dipakainya istilah granat atau ranjau, istilah darurat. Hal tersebut menggambarkan mental masyarakat yang masih menghiperbolakan kekuatan dan kedigdayaan militer.

e. Masyarakat berubah dan berkembang, begitu pula dengan kondisi kebahasaannya yang dinamis. Namun demikian dapat dilihat bahwa masyarakat urban yang militan berjuang setiap hari belum sampai pada titik perlawanan, minimal dari upaya pemilihan istilah ketika mereka menamai produk atau dagangan yang dijualnya. Masyarakat yang terhegemoni belum sampai pada titik menjadi penyintas, masih meratapi nasib dan baper asosiatif lewat namanama kuliner yang diciptakannya.

f. Upaya membangun mental masyarakat agar tidak terus merasa sebagai pihak terhegomoni bisa diawali dengan penciptaan frasa-frasa atau istilahistilah kuliner yang optimis, misalnya Bakso Ceria, Ayam Ketawa, dan lain-lain. 


\section{DAFTAR PUSTAKA}

Chaer, Abdul. 2002. Pengantar Semantik Bahasa Indonesia. Jakarta: Rineka Cipta.

Eco, Umberto. 2009. Teori Semiotika Signifikasi Komunikasi, Teori Kode, serta Teori Produksi Tanda. Yogyakarta: Kreasi Wacana.

Kridalaksana, Harimurti. 2008. Kamus Linguistik. Jakarta: Gramedia.

Mahsun. 2014. Metode Penelitian Bahasa. Jakarta: Rajawali Pers.

Parera, J.D. 2004. Teori Semantik. Jakarta : Erlangga,

Pateda, Masoer. 2010. Semantik Leksikal. Jakata: Rineka Cipta.

Rahardi, Kunjana. 2009. Bahasa Prevoir Budaya. Yogyakarta: Pinus Book Publisher.

Samarin, William, J. Ilmu Bahasa Lapangan. Yogyakarta: Kanisius.

Sudaryanto. 1993. Metode dan Aneka Teknik Analisis Bahasa. Yogyakarta: Duta Wacana University Press

Ullman, Stephen. 2009. Pengantar Semantik. Yogyakarta: Pustaka Pelajar.

Verhaar, JWM. 2008. Asas-Asas Linguistik Umum. Yogyakarta: Gajah Mada University Press. 